\title{
Calculating a Consistent Terminal Value in Multistage Valuation Models
}

\author{
Larry C. Holland ${ }^{1}$ \\ ${ }^{1}$ College of Business, University of Arkansas Little Rock, Little Rock, AR, USA \\ Correspondence: Larry C. Holland, University of Arkasnsas Little Rock, Little Rock, AR 72204.
}

Received: October 2, 2017

Accepted: October 16, 2017

Online Published: October 30, 2017

doi:10.5430/afr.v7n1p1

URL: https://doi.org/10.5430/afr.v7n1p1

\begin{abstract}
Valuation analysis based on the present value of future cash flows often requires a multistage valuation model which includes a terminal value. An accurate calculation of the terminal value is very important, particularly if it represents a significant portion of the stock price. A typical analysis would include a finite forecast of cash flows for a five to ten-year period followed by a terminal value that represents all the cash flows thereafter. A common assumption is that the valuation cash flows beyond the finite horizon simply continue to grow at a lower long-term growth rate. A pro forma analysis clearly demonstrates that such an assumption is rarely appropriate except under very restrictive assumptions, if consistent accounting relationships are maintained. The analysis in this paper uses dividends as the valuation cash flows in an example calculation to clarify this issue. A closed-form equation is developed that defines a step function increase in dividends at the point where the growth rate declines, without the need for a pro forma analysis. The size of the step function increase is then shown to change when the values of various key value drivers in the analysis are also allowed to change. Such value drivers include the EBIT margin, the asset intensity, and the relative level of debt. The step function increase in dividends can have a significant effect on the size of the terminal value and highlights the importance of maintaining consistent accounting relationships when forecasting future cash flows in a multistage valuation model.
\end{abstract}

Keywords: Valuation, Terminal value, Multistage model, Consistent accounting, Value drivers

\section{JEL Classification: G12, G17, C20, C65}

\section{Introduction}

Analysts routinely use multistage valuation models with a terminal value to calculate the present value of estimated future cash flows in order to recommend a fair price for a stock today. A very common approach is to use a higher growth rate for a five to ten-year period, and then a smaller long-term growth thereafter as the firm reaches a more mature phase. However, a change to a smaller growth rate frequently increases the cash flows from a company.

For example, the life cycle theory of the firm suggests that a young firm typically has a high growth rate which declines over time to a lower, mature growth rate. The higher growth rate for a young firm typically leads to a significant need for cash to support that growth, while the lower growth for a mature firm often results in significant excess cash. As a result, a mature firm is often characterized as a "cash cow" and is expected to pay a higher level of dividends. Therefore, when the growth rate of a company begins to slow down as it approaches maturity, the retention rate will likely decrease and the level of dividends will increase.

In terms of a valuation model, the financial variables in a forecast such as the growth rate, the operating profit margin, the capital intensity, and the capital structure need to remain in a consistent accounting relationship as a company transitions from a normal growth rate to a slower growth at maturity. In this paper, an example valuation with detailed pro forma estimates will demonstrate that the level of dividends increases by a step function when the growth rate is decreased to a long-term, mature rate, which typically occurs at the terminal value in a multistage valuation. This illustrates that the calculation of a consistent terminal value is very important to valuation analysis.

\section{Literature Review}

There are several examples in the literature in which a step function increase in the valuation cash flows is not recognized when there is a decrease in the growth rate of a firm. Textbooks about investments provide the mechanics for multistage valuation but generally ignore any step function increase in valuation cash flows when the growth rate declines. For example, Bodie, Kane, and Marcus (2017) illustrate a two-stage valuation in which the dividend growth 
decreases from a level of $12 \%$ to $7.68 \%$, which adjusts for an appropriate ROE and retention rate (see Bodie et al., 2017, p. 415). However, they show no step function change in the level of dividends in the terminal value calculation. Reilly and Brown (2006) and McMillan (2011) show similar examples with no step function change. In other literature, Claus and Thomas (2001) document a methodology for calculating the implied cost of equity. Their calculation of a terminal value also assumes a constant growth from a 4-year finite growth period without any step function increase (see Claus \& Thomas, 2001, p. 1636). One of the reasons for omitting a step function increase in the valuation cash flows when there is a decrease in the growth rate is because it requires a more comprehensive analysis. Penman (1997) points out the need for a pro forma analysis to accurately determine the cash flows in the terminal value calculation. Penman (1997) states,

The terminal value calculation amounts to forecasting future stocks and flows and weighting them to yield one number. The weights are determined by a parameter that reflects the accounting principles for measuring stocks and flows. This parameter, along with the forecasted stocks and flows to be combined, is discovered from pro forma analysis. (Penman (1997), p. 304).

There is a gap in the literature on identifying a change in the level of valuation cash flows in a straightforward manner, other than through a pro forma analysis.

There are a few references in the literature that indicate an increase in the valuation cash flows at the point of a continuing terminal value when there is a decrease in the growth rate of a firm. For example, Damodaran (2012) documents the mechanics of equity valuation and illustrates a two-stage valuation of Proctor and Gamble (see Damodaran, 2012, p. 332). Year 5 of the example shows a step function increase of the dividend from 3.08 per share to 4.75 per share when the growth rate in earnings decreases from $10 \%$ to $3 \%$ per year. The mature growth rate is then matched with a mature reinvestment rate using a form of the sustainable growth rate developed by Higgins (1977), which assumes that key values drivers remain constant.

Koller, Goedhart, and Wessels (2010) point out that a step function increase in the valuation cash flows should be expected when the future growth rate decreases to a long-term level near the growth in the overall economy. They state,

The typical error is to estimate incorrectly the level of free cash flow that is consistent with the growth rate being forecast. If growth in the continuing value period is forecast to be less than the growth in the explicit forecast period (as is normally the case) ... the continuing value could be significantly understated. (Koller et al., 2010, pp. 215-216).

Then in an example calculation, Koller et al. (2010) illustrate that the valuation cash flow increases with a step function at the continuing value that is $18 \%$ higher than a simple increase from the mature growth rate in the continuing value period (see Koller et al., 2010, p. 225).

Pinto, Robinson, and Stowe (2010) provide a clear example of a step function increase in Free Cash Flow to Equity (FCFE) when there is a decrease in the growth rate of the firm. The FCFE represents the potential dividend that could be paid to stockholders. In their example of a two-stage valuation, the decrease in the growth occurs after three years of high growth. They state,

Then between years 3 and 4, when the sales growth drops from 20 percent to 6 percent, FCFE increases substantially. In fact, FCFE increases by $169 \%$ from year 3 to year 4 . This large increase in FCFE occurs because profits grow at 6 percent but the investments in capital equipment and working capital (and the decrease in debt financing) drop substantially from the previous year. In years 5 and 6, in Exhibit 4-15, sales, profits, investment, financing, and FCFE are all shown to grow at 6\%. (Pinto et al., 2010, p. 188).

Pinto et al. (2010) use a simplified form of pro forma forecasting to illustrate the calculation in their example and hold everything else constant, including the value drivers.

There are two main contributions in this paper. First, a closed form equation is developed to quantify a step function increase in dividends when the growth rate declines, without the need for a pro forma analysis. This provides a convenient means for calculating an appropriate terminal value. A second contribution is an expansion of this equation to identify the effects of changes in key value drivers that occur along with a change in the growth rate. This fills a gap in the literature and provides a flexible method for calculating a terminal value that incorporates changes that are expected to occur over time in a firm.

This paper is divided into six additional sections. The third section sets the stage with a basic introduction and background for the simplest multi-stage valuation model. The fourth section focuses on the calculation of an 
appropriate growth rate to drive the valuation analysis. The next two sections utilize a pro forma forecast over multiple years to illustrate the concept of finding more value in multistage valuation models, including changes in key value drivers. The seventh section shows a calculation of the terminal value, which leads to the current value of the stock. This calculation includes a closed form equation for finding the step function increase in dividends and the effect of changes in the key value drivers. Finally, the last section is a summary of the paper.

\section{Background}

At the most fundamental level, the cash flows to the holder of a stock are the future dividends. Thus, the value of a stock would be the present value of all expected future dividends, or

$$
V_{0}=\sum_{t=1}^{\infty} \frac{D_{t}}{\left(1+R_{E}\right)^{t}}
$$

where $\quad \mathrm{V}_{0}=$ the value at time zero,

$\mathrm{D}_{\mathrm{t}} \quad=$ the dividend at time $\mathrm{t}$, and

$\mathrm{R}_{\mathrm{E}} \quad=$ the required rate of return for equity cash flows.

As a practical matter, estimating future dividends over an extended period of time can be difficult. Therefore, models have been developed that simplify the present value of future dividends. The most widely recognized of these models is the constant dividend growth model, mentioned by Williams (1938) and then popularized by Gordon and Shapiro (1956) and Gordon (1962).

$$
V_{0}=\frac{D_{1}}{R_{E}-g_{n}}
$$

where $\quad g_{n}=a$ constant long-term growth rate.

An estimate of the long-term growth rate in this model must be less than the required return on equity and normally should be no larger than the long-term growth in the overall economy. This restriction limits the direct application of this model because the current growth rate is frequently larger than the estimated long-term growth in the economy, and often larger than the required return on equity. Thus, a direct application of the constant dividend model for valuation is generally restricted to a very few mature companies with stable cash flows and low growth.

More commonly, the constant dividend growth model is applied in a two-stage model. In this case, dividends are estimated for a finite number of years $(\mathrm{T})$ using a faster growth rate. Then a terminal value $\left(\mathrm{V}_{\mathrm{T}}\right)$ estimates the remaining dividends with the constant dividend growth model using a low long-term growth rate $\left(\mathrm{g}_{\mathrm{n}}\right)$ suitable for a mature company, as follows:

$$
V_{0}=\sum_{t=1}^{T} \frac{D_{t}}{\left(1+R_{E}\right)^{t}}+\frac{V_{T}}{\left(1+R_{E}\right)^{T}}
$$

where

$$
V_{T}=\sum_{t=1}^{\infty} \frac{D_{T+t}}{\left(1+R_{E}\right)^{t}}=\frac{D_{T+1}}{\left(R_{E}-g_{n}\right)}
$$

Of particular importance is the dividend used to calculate the terminal value at the point of transition in growth rates to a lower long-term rate. For example, suppose an analyst assumes a significant decrease in growth from an extraordinary high growth of $\mathrm{g}$ prior to time $\mathrm{T}$ down to a normalized lower mature growth ${ }$ of $\mathrm{g}_{\mathrm{n}}$ from time $\mathrm{T}+1$ forward. Estimating the dividend at time $\mathrm{T}+1$ (i.e., $\mathrm{D}_{\mathrm{T}+1}$ ), is often not straightforward. Although it might seem appropriate, a generally incorrect method of calculating $\mathrm{D}_{\mathrm{T}+1}$ when there is a decrease in growth rate from $\mathrm{g}$ to $\mathrm{g}_{\mathrm{n}}$ is to assume that

$$
D_{T+1}=\left(1+g_{n}\right) D_{T}
$$


Equation 5 will only be true under a specific and somewhat restrictive set of assumptions, which are often unrealistic. In many cases, a decrease in growth while maintaining consistent accounting relationships will increase the level of cash flows more than growing at the lower mature growth rate would imply. This means that a decrease in the growth rate of a firm will often result in a step function increase in the level of dividends, beyond just continuing to grow at a lower mature growth rate.

As a hypothetical example, one might assume that the current growth rate is temporarily high at $12 \%$ per year and would continue for a number of years; then a terminal value would reflect a constant $2 \%$ growth thereafter. Note that a low growth rate for the terminal value is not really a precise forecast that the growth rate will drop suddenly after a given number of years. Instead, the low growth rate is an artifact of the models we use to calculate the present value of future cash flows - the terminal value is a placeholder for all the remaining cash flows, which at the same time acknowledges that only a low growth rate assumption is appropriate for long-term growth in a mature firm. The sudden drop in growth rate is simply a rough (and probably conservative) way to show that the current growth rate will eventually be much lower in the future when the firm is mature, but would not necessarily designate a particular path to the future. In real life, the growth rate of a firm will more likely decline gradually over time. Likewise, in this paper, the forecast of a decline in growth is not predicting a precise sudden increase in cash flows at the point where the terminal value is applied. Rather, a method is provided for calculating a level of cash flows consistent with an accounting balance and the assumptions for future growth.

\section{Defining the Future Cash Flows and Growth Rates}

The future cash flows used in the constant dividend growth model are the future dividends, which are the only direct cash flows to equity shareholders. Capital gains from an increase in stock prices would then reflect an increased capacity to pay larger dividends in the future. From this viewpoint, anticipated future dividends are the most direct cash flows for applying valuation to equity shares. Of course, the constant growth model could be applied to other cash flows as well. In this paper, the focus is on dividends as the primary valuation cash flows. However, similar effects occur with other valuation cash flows as well, such as free cash flow to the firm (FCFF) and free cash flow to equity (FCFE).

Dividends, FCFF, and FCFE are all a function of other variables in the valuation analysis. For example, the operating profitability of the firm (EBIT/Sales), the asset efficiency (IC/Sales), and the capital structure (Debt/IC) are often identified as value drivers in equity valuation analysis. Changes in these other variables complicate the determination of the future growth rates for the valuation cash flows to be used in the valuation analysis. This means that the growth rates over time for earnings before interest and taxes (EBIT), net income, and dividends can be significantly different from each other if the value drivers change over time. Changes in growth rates also affect the absolute levels of cash flows in a step function manner, which again complicates valuation analysis.

The approach used in this paper is to place primary focus on the growth in sales, and then determine the level and growth rate of the resulting cash flows including changes in the key value drivers. The key value drivers are identified as the growth in sales (g), (EBIT/Sales), (IC/Sales), and (Debt/IC). An advantage of focusing on the growth in sales as an initial driving force is that it is often useful to observe actual historical growth rates when estimating future growth rates. In this case, calculating the historical compounded growth in sales is very straightforward compared to calculating the growth rate in the resulting cash flows, such as dividends, FCFF, and FCFE. For example, sales are always positive. Therefore, a geometric growth rate or a log regression mean growth rate can easily be determined. However, such a compounded approach requires that all values be positive. In contrast, EBIT and net income can occasionally be negative. Thus, an appropriate compounded growth rate can be difficult and sometimes impossible to calculate for these variables. Even if normalized positive values are somehow assumed or generated, the result would then be a less objective measure of the growth rate. As a result, the approach in this paper is to use the growth in sales to drive the determination of resulting cash flows in the valuation analysis, and then to determine the effect of changes in the other three key value drivers.

\section{A Pro Forma Forecast Over Multiple Years - No Change in Key Value Drivers}

A pro forma forecast over multiple years for an example company will be used to illustrate the effect of changing the growth rate in a multistage valuation analysis. This analysis will demonstrate that the absolute level of dividends will often change in a step function manner when the growth rate changes (such as at a terminal value), assuming that consistent accounting relationships are maintained. Table 1 shows the financial statements for an example company with a pro forma forecast of 4 years into the future. 
Table 1. Example Financial Statements: $g=12 \%$ to $2 \%$ after Year 2, Value Drivers Constant

\begin{tabular}{|c|c|c|c|c|c|}
\hline & Actual & $\begin{array}{c}\text { Year } 1 \\
\mathrm{~g}=12 \%\end{array}$ & $\begin{array}{c}\text { Year } 2 \\
\mathrm{~g}=12 \%\end{array}$ & $\begin{array}{c}\text { Year } 3 \\
\mathrm{~g}=2 \%\end{array}$ & $\begin{array}{l}\text { Year } 4 \\
\mathrm{~g}=2 \%\end{array}$ \\
\hline \multicolumn{6}{|l|}{ Income Statement } \\
\hline Sales & 200 & 224.00 & 250.88 & 255.90 & 261.02 \\
\hline CGS & 150 & 168.00 & 188.16 & 191.92 & 195.76 \\
\hline SG\&A & 10 & 11.20 & 12.54 & 12.79 & 13.05 \\
\hline Depreciation & 10 & 11.20 & 12.54 & 12.79 & 13.05 \\
\hline EBIT & 30 & 33.60 & 37.63 & 38.38 & 39.15 \\
\hline Interest Expense & 5 & 5.60 & 6.27 & 6.40 & 6.53 \\
\hline$\overline{\mathrm{EBT}}$ & $\overline{25}$ & 28.00 & 31.36 & $\overline{31.99}$ & 32.63 \\
\hline Taxes@ @0\% & 10 & 11.20 & 12.54 & 12.79 & 13.05 \\
\hline Net Income & 15 & 16.80 & 18.82 & 19.19 & 19.58 \\
\hline Dividends & 4 & 4.80 & 5.38 & 16.68 & 17.02 \\
\hline Additions to RE & 11 & 12.00 & 13.44 & 2.51 & 2.56 \\
\hline Retention Rate (b) & 0.7333 & 0.7143 & 0.7143 & 0.1307 & 0.1307 \\
\hline \multicolumn{6}{|l|}{ Balance Sheet } \\
\hline Cash & 5 & 5.60 & 6.27 & 6.40 & 6.53 \\
\hline Accounts Receivable & 15 & 16.80 & 18.82 & 19.19 & 19.58 \\
\hline Inventory & 30 & 33.60 & 37.63 & 38.38 & 39.15 \\
\hline Current Assets & 50 & 56.00 & 62.72 & 63.97 & 65.25 \\
\hline Net Fixed Assets & 120 & 134.40 & 150.53 & 153.54 & 156.61 \\
\hline Total Assets & 170 & 190.40 & 213.25 & 217.51 & 221.86 \\
\hline Current Liabilities & 20 & 22.40 & 25.09 & 25.59 & 26.10 \\
\hline LT Debt & 50 & 56.00 & 62.72 & 63.97 & 65.25 \\
\hline Common Stock & 20 & 20 & 20 & 20 & 20 \\
\hline$\underline{\text { Retained Earnings }}$ & 80 & 92.00 & 105.44 & 107.95 & 110.51 \\
\hline Total L\&OE & 170 & $\overline{190.40}$ & 213.75 & 217.51 & 221.86 \\
\hline \multicolumn{6}{|l|}{ Invested Capital } \\
\hline LT Debt & 50 & 56.00 & 62.72 & 63.97 & 65.25 \\
\hline Common Stock & 20 & 20 & 20 & 20 & 20 \\
\hline Retained Earnings & 80 & 92.00 & 105.44 & 107.95 & 110.51 \\
\hline Total Equity & 100 & 112.00 & 125.44 & 127.95 & 130.51 \\
\hline Invested Capital & 150 & 168.00 & 188.16 & 191.92 & 195.76 \\
\hline Capital Expenditures & & 25.60 & 28.67 & 15.81 & 16.12 \\
\hline FCFF & & 2.16 & 2.42 & 19.27 & 19.65 \\
\hline FCFE & & 4.80 & 5.38 & 16.68 & 17.02 \\
\hline Residual Income & & 1.80 & 2.02 & 0.38 & 0.38 \\
\hline EBIT/Sales & $15.00 \%$ & $15.00 \%$ & $15.00 \%$ & $12.00 \%$ & $12.00 \%$ \\
\hline IC/Sales & 0.7500 & 0.7500 & 0.7500 & 0.9000 & 0.9000 \\
\hline Debt/IC Ratio & $33.33 \%$ & $33.33 \%$ & $33.33 \%$ & $50.00 \%$ & $50.00 \%$ \\
\hline Return on Equity & $15.00 \%$ & $15.00 \%$ & $15.00 \%$ & $15.00 \%$ & $15.00 \%$ \\
\hline ROIC & $12.00 \%$ & $12.00 \%$ & $12.00 \%$ & $12.00 \%$ & $12.00 \%$ \\
\hline
\end{tabular}


The sales are assumed to grow at $12 \%$ per year for two years, and thereafter will grow at a long-term mature rate of $2 \%$ per year. In this first analysis, the three value drivers of (EBIT/Sales), (IC/Sales), and (Debt/IC) are assumed to remain constant. In year 3, the growth rate in sales is assumed to decrease from $12 \%$ to $2 \%$ per year. Note that the level of dividends increases dramatically in a step function manner from 5.38 in Year 2 to 16.68 in Year 3. This is significantly larger than a $2 \%$ growth after Year 2, which would be a dividend of 5.49 in Year 3. The reason for this step function increase in dividends is a direct result of a decrease in the growth in sales. The smaller increase in sales requires a smaller increase in invested capital to supply the extra sales, which in turn requires a smaller increase in equity. The primary increase in equity is from internally generated funds in terms of the additions to retained earnings. With a smaller need for additions to retained earnings from net income, more funds are available for distribution as dividends. Thus, a decrease in the growth of sales leads directly to a step function increase in the level of dividends. After the step function increase, dividends continue to grow at the same growth rate as sales.

This example clearly points out that the dividend in any particular year does not always equal the dividend in the previous year multiplied by $(1+\mathrm{g})$ when there is a significant change in the growth rate. The example also demonstrates that maintaining consistency among assumptions is very important. In this case, there is a significant increase in cash flows at the point where the growth rate is assumed to decline. Thus, any change in growth rate should normally be accompanied by a step function change in the level of the cash flows.

In a more general sense, the level of dividends is a direct function of the change in the level of equity required to support the growth in the firm, assuming that the key value drivers remain constant. This means that the dividend will change in a 1-year step function manner when the equity changes because of a decrease in the growth rate. The Appendix to this paper shows in Equation 39 that the change in dividends when the growth rate changes from $g_{t}$ to $\mathrm{g}_{\mathrm{t}+1}$ can be calculated directly without the need of a pro forma statement, as follows:

$$
D I V_{t+1}=D I V_{t}\left(1+g_{t+1}\right)+\left[g_{t} \frac{\left(1+g_{t+1}\right)}{\left(1+g_{t}\right)}-g_{t+1}\right] \text { Equity }_{t}
$$

Equation 6 includes the assumption that the other three value drivers are constant. Plugging in values into Equation 6 illustrates the usefulness of this equation:

$$
D I V_{t+1}=5.38(1.02)+\left[.12 \frac{(1.02)}{(1.12)}-.02\right] 125.44=5.49+11.20=16.69
$$

The second term in Equation 6 represents a 1-year step function change in dividends of 11.20 when there is a decrease in the sales growth rate from $12 \%$ to $2 \%$. Thus, similar to the pro forma financial statements, a decrease in the growth rate of sales results in a corresponding step function increase in the level of dividends. Note that if the growth rate remains constant from year to year, the step function term becomes equal to zero, and then $\operatorname{DIV}_{t+1}=\mathrm{DIV}_{t}$ $\left(1+g_{t+1}\right)$. This again illustrates the importance of counting the impact of a reduction in the growth rate over time.

\section{A Pro Forma Forecast with Changes in the Key Value Drivers}

Table 2 shows the effect that changes in the three value drivers have on the step function increase in dividends when they are included in the analysis. Changes in the value drivers are introduced in Year 3 and have a complex and interrelated effect on the valuation cash flows. 
Table 2. Example Financial Statements: $g=12 \%$ to $2 \%$ after Year 2, Value Drivers Change

\begin{tabular}{|c|c|c|c|c|c|}
\hline & Actual & $\begin{array}{c}\text { Year } 1 \\
\mathrm{~g}=12 \%\end{array}$ & $\begin{array}{c}\text { Year } 2 \\
\mathrm{~g}=12 \%\end{array}$ & $\begin{array}{l}\text { Year } 3 \\
\mathrm{~g}=2 \%\end{array}$ & $\begin{array}{l}\text { Year } 4 \\
\mathrm{~g}=2 \%\end{array}$ \\
\hline \multicolumn{6}{|l|}{ Income Statement } \\
\hline Sales & 200 & 224.00 & 250.88 & 255.90 & 261.02 \\
\hline CGS & 150 & 168.00 & 188.16 & 191.92 & 195.76 \\
\hline SG\&A & 10 & 11.20 & 12.54 & 12.79 & 13.05 \\
\hline Depreciation & 10 & 11.20 & 12.54 & 17.06 & 17.40 \\
\hline EBIT & 30 & 33.60 & 37.63 & 30.71 & 31.32 \\
\hline Interest Expense & 5 & 5.60 & 6.27 & 12.79 & 13.05 \\
\hline EBT & 25 & 28.00 & 31.36 & 17.91 & 18.17 \\
\hline Taxes@40\% & 10 & 11.20 & 12.54 & 7.17 & 7.31 \\
\hline Net Income & 15 & 16.80 & 18.82 & 10.75 & 10.96 \\
\hline$\underline{\text { Dividends }}$ & 4 & 4.80 & 5.38 & 8.24 & 8.40 \\
\hline$\overline{\text { Additions to RE }}$ & 11 & 12.00 & 13.44 & 2.51 & 2.56 \\
\hline Retention Rate (b) & 0.7333 & 0.7143 & 0.7143 & 0.2334 & 0.2334 \\
\hline \multicolumn{6}{|l|}{ Balance Sheet } \\
\hline Cash & 5 & 5.60 & 6.27 & 8.53 & 8.70 \\
\hline Accounts Receivable & 15 & 16.80 & 18.82 & 25.59 & 26.10 \\
\hline Inventory & 30 & 33.60 & 37.63 & 51.18 & 52.20 \\
\hline Current Assets & 50 & 56.00 & 62.72 & 85.30 & 87.01 \\
\hline Net Fixed Assets & 120 & 134.40 & 150.53 & 204.72 & 208.81 \\
\hline Total Assets & 170 & 190.40 & 213.25 & 290.02 & 295.82 \\
\hline Current Liabilities & 20 & 22.40 & 25.09 & 34.12 & 34.80 \\
\hline LT Debt & 50 & 56.00 & 62.72 & 127.95 & 130.51 \\
\hline Common Stock & 20 & 20 & 20 & 20 & 20 \\
\hline$\underline{\text { Retained Earnings }}$ & 80 & 92.00 & 105.44 & 107.95 & 110.51 \\
\hline Total L\&OE & $\overline{170}$ & $\overline{190.40}$ & 213.75 & 290.02 & 295.82 \\
\hline \multicolumn{6}{|l|}{ Invested Capital } \\
\hline LT Debt & 50 & 56.00 & 62.72 & 127.95 & 130.51 \\
\hline Common Stock & 20 & 20 & 20 & 20 & 20 \\
\hline Retained Earnings & 80 & 92.00 & 105.44 & 107.95 & 110.51 \\
\hline Total Equity & 100 & 112.00 & 125.44 & 127.95 & 130.51 \\
\hline Invested Capital & 150 & 168.00 & $\overline{188.16}$ & 255.90 & $\overline{261.02}$ \\
\hline Capital Expenditures & & 25.60 & 28.67 & 71.25 & 21.50 \\
\hline FCFF & & 2.16 & 2.42 & -49.31 & 13.68 \\
\hline FCFE & & 4.80 & 5.38 & 8.24 & 8.40 \\
\hline Residual Income & & 1.80 & 2.02 & -8.07 & -8.23 \\
\hline EBIT/Sales & $15.00 \%$ & $15.00 \%$ & $15.00 \%$ & $12.00 \%$ & $12.00 \%$ \\
\hline IC/Sales & 0.7500 & 0.7500 & 0.7500 & 1.0000 & 1.0000 \\
\hline Debt/IC Ratio & $33.33 \%$ & $33.33 \%$ & $33.33 \%$ & $50.00 \%$ & $50.00 \%$ \\
\hline Return on Equity & $15.00 \%$ & $15.00 \%$ & $15.00 \%$ & $12.00 \%$ & $12.00 \%$ \\
\hline ROIC & $12.00 \%$ & $12.00 \%$ & $12.00 \%$ & $7.20 \%$ & $7.20 \%$ \\
\hline
\end{tabular}


The changes in the value drivers are identified as multiplicative factors. For example, a factor of $\mathrm{f}_{\mathrm{EBIT}}=0.8$ means that the EBIT margin changes from $15 \%$ to $12 \%$ in Year 3. Likewise, a factor of $f_{\text {IC }}=1.333$ means that the invested capital turnover changes from 0.75 to 1.00 in Year 3. And finally, a factor of $f_{\text {Debt }}=1.5$ means that the debt to invested capital ratio changes from 0.333 to 0.5 in Year 3. These three changes are quite large, but illustrate the concept of how changes in the key value drivers affect the step function increase in dividends. Equation 38 in the Appendix shows an expansion of Equation 6 to include the effect of changes in the key value drivers, as follows:

$$
\begin{aligned}
\text { DIV }_{t+1}=(1+ & \left.g_{t+1}\right) \text { DIV } \\
+ & {\left[g_{t} \frac{\left(1+g_{t+1}\right)}{\left(1+g_{t}\right)}-g_{t+1}\right] \text { Equity }_{t} } \\
-\left(1-f_{E B I T}\right) & \left(1+g_{t+1}\right)(1-\text { tax }) E B I T_{t} \\
& -\left(f_{\text {Debt }} f_{I C}-1\right)\left(1+g_{t+1}\right)(1-\text { tax })\left(\text { i Debt }_{t}\right) \\
& \quad-\left(f_{I C}-1\right)\left(1+g_{t+1}\right) \text { Equity }_{t} \\
& +f_{I C}\left(f_{\text {Debt }}-1\right)\left(1+g_{t+1}\right) \text { Debt }_{t}
\end{aligned}
$$

Note that the second term remains the same with a step function increase in the level of dividends beyond the normal growth at the mature growth rate. Then, there are also increases and decreases as a result of changes in the value drivers. For example, a decrease in the EBIT/Sales margin $\left(f_{\mathrm{EBIT}}<1\right)$ will have a negative effect on the step function increase in dividends through a decrease in profitability. At the same time, an increase in the IC/Sales asset intensity $\left(f_{\mathrm{IC}}>1\right)$ will have a negative effect because of lower efficiency of the invested capital. However, an increase in the Debt/IC ratio $\left(f_{\text {Debt }}>1\right)$ has a negative effect through an increase in the interest expense and a positive effect from the extra funds from an increase in debt. Again, plugging values into Equation 8 illustrates numerically how changes in the three value drivers affect the step function change in dividends at the point of decrease in the sales growth:

$$
\begin{aligned}
& D I V_{t+1}=5.48+11.20 \\
& -(1-0.8)(1.02)(1-0.40) 37.63 \\
& \quad-[(1.5)(1.333)-1](1.02)(1-0.40)(0.10)(62.72) \\
& -(1.333-1)(1.02) 125.44 \\
& +1.333(1.5-1)(1.02) 62.72 \\
& \quad=16.69-4.61-3.84-42.65+42.65=8.24
\end{aligned}
$$

Stepwise, the growth in the dividend at the mature growth rate increases the dividend to 5.48. Then, a step function of 11.20 increases the dividend to 16.69. Finally, the changes in the three key value drivers has a combined effect of reducing the level of dividends at time $\mathrm{t}+1$ from 16.69 to 8.24 .

\section{Valuing the Cash Flows}

The effect on valuation can be significant. Assuming a $15 \%$ required return on equity and holding the key value drivers constant, the value of the normal growth in dividends plus the step function increase would be

$$
\begin{gathered}
V_{2}=\frac{D_{3}}{R-g}=\frac{16.684}{.15-.02}=128.338 \\
V_{0}=\frac{D_{1}}{(1+R)}+\frac{D_{2}}{(1+R)^{2}}+\frac{V_{2}}{(1+R)^{2}} \\
V_{0}=\frac{4.80}{(1.15)}+\frac{5.376}{(1.15)^{2}}+\frac{128.338}{(1.15)^{2}}=4.174+4.065+97.042=105.281 \\
V_{0}=105.28
\end{gathered}
$$

If the step function increase in dividends is not counted, then the value per share would be much lower. In this case, the dividend in year 3 would be $\mathrm{D}_{3}=\mathrm{D}_{2}\left(1+\mathrm{g}_{\mathrm{n}}\right)$. Then the value per share would be 


$$
\begin{gathered}
V_{2}=\frac{D_{3}}{R-g_{n}}=\frac{D_{2}\left(1+g_{n}\right)}{R-g_{n}}=\frac{5.376(1.02)}{.15-.02}=\frac{5.484}{.15-.02}=42.181 \\
V_{0}=\frac{D_{1}}{(1+R)}+\frac{D_{2}}{(1+R)^{2}}+\frac{V_{2}}{(1+R)^{2}} \\
V_{0}=\frac{4.800}{(1.15)}+\frac{5.376}{(1.15)^{2}}+\frac{42.181}{(1.15)^{2}}=4.174+4.065+31.895=40.136 \\
V_{0}=40.14
\end{gathered}
$$

In this example, the value of the equity more than doubles from $\$ 40.14$ to $\$ 105.28$ when the step function increase in dividends is included, which directly affects the size of the terminal value. When the key value drivers are also allowed to change over time, the valuation is again decreased somewhat to

$$
\begin{gathered}
V_{2}=\frac{D_{3}}{R-g_{n}}=\frac{D_{2}\left(1+g_{n}\right)}{R-g_{n}}=\frac{8.239}{.15-.02}=63.376 \\
V_{0}=\frac{D_{1}}{(1+R)}+\frac{D_{2}}{(1+R)^{2}}+\frac{V_{2}}{(1+R)^{2}} \\
V_{0}=\frac{4.800}{(1.15)}+\frac{5.376}{(1.15)^{2}}+\frac{63.376}{(1.15)^{2}}=4.174+4.065+47.922=56.161 \\
V_{0}=56.16
\end{gathered}
$$

The combined effect of a decline in growth and changes in the key value drivers decreases the resulting valuation. However, the stock value is still $40 \%$ higher than a simple assumption that the dividend continues to grow at a long-term, mature growth rate. Thus, it is clear that there is a potential for finding significantly more value in multistage valuation models if consistent accounting relationships are maintained in the calculation of the terminal value.

\section{Summary}

This paper demonstrates that an analyst must be very careful in determining a terminal value in a multistage valuation model. Specifically, there frequently may be additional value in the terminal value when the growth rate is assumed to decrease to a level near the long-term growth of the economy. A simple example is used to illustrate this effect through a pro forma analysis. Given a consistent set of assumptions, it is shown that the level of dividends increases by a step function when the growth rate declines, which is often significantly higher than a simple projection of growth rates would indicate. This step function increase in dividends directly increases the size of the terminal value and the stock valuation. This is true even if key value drivers are allowed to change as well. The simple pro forma analysis is extended to include changes in the operating profit margin, the asset intensity, and the relative level of debt in the capital structure. Finally, a closed-form equation is derived so that the step function increase in dividends can be determined without the need for a pro forma analysis, including changes in the key value drivers. Therefore, the example valuations demonstrate the importance of maintaining consistent accounting relationships in the calculation of the terminal value and the total stock value.

\section{References}

Bodie, Z., Kane, A., \& Marcus, A. (2017). Essentials of Investments $10^{\text {th }}$ Ed. New York: McGraw Hill.

Claus, J. \& Thomas, J. (2001). Equity premia as low as three percent. Journal of Finance, 56, 1629-1666. https://doi.org/10.1111/0022-1082.00384

Damodaran, A. (2012). Investment Valuation (University Edition) $3^{\text {rd }}$ Ed. Hoboken, N.J.: John Wiley and Sons.

Gordon, M. (1962). The Investment, Financing, and Valuation of the Corporation. IL: Richard D. Irwin.

Gordon, M. \& Shapiro, E. (1956). Capital equipment analysis: The required rate of profit. Management Science, 3(1), 102-110. https://doi.org/10.1287/mnsc.3.1.102

Higgins, R. (1977). How much growth can a firm afford. Financial Management, 6(3), 7-16. https://doi.org/10.2307/3665251 
Koller, T., Goedhart, M. \& Wessels, D. (..2010). Valuation: Measuring and Managing the Value of Companies, $5^{\text {th }}$ University Ed. Hoboken, NJ: John Wiley and Sons.

McMillan, M (2011). Investments: Principles of Portfolio and Equity Analysis. Hoboken, NJ: John Wiley and Sons.

Penman, S. (2015). Valuation models: An issue of accounting theory. In S. Jones (Ed.), Routledge Companion to Financial Accounting Theory (pp. 236-253). New York, NY: Routledge.

Penman, S. (1997). A synthesis of equity valuation techniques and terminal value calculation for the dividend discount model. Review of Accounting Studies, 2, 303-323. https://doi.org/10.1023/A:1023688704798

Pinto, J., Henry, E., Robinson, T. \& Stowe, J. (2010). Equity Asset Valuation, $2^{\text {nd }}$ Ed. Hoboken, NJ: John Wiley and Sons.

Reilly, F. \& Brown, K. (2006). Investment Analysis and Portfolio Management $8^{\text {th }}$ Ed. Mason Ohio: Thomson South-Western.

Williams, J. B. (1938). The Theory of Investment Value. 1997 reprint, Fraser Publishing, c1938, Cambridge: Harvard University Press.

\section{Appendix}

Summary of Assumptions:

Constant interest rate $(i=$ INT/Debt $)$, or

$\mathrm{INT}_{\mathrm{t}} / \mathrm{Debt}_{\mathrm{t}}=\mathrm{INT}_{\mathrm{t}+1} / \mathrm{Debt}_{\mathrm{t}+1}$

Constant tax rate (tax), or

$\operatorname{tax}_{\mathrm{t}}=\operatorname{tax}_{\mathrm{t}+1}$

Sales grow $g_{t}$ between time $t-1$ and $t$, or

$\operatorname{Sales}_{\mathrm{t}}=\operatorname{Sales}_{\mathrm{t}-1}\left(1+\mathrm{g}_{\mathrm{t}}\right)$

Sales grow $\mathrm{g}_{\mathrm{t}+1}$ between time $\mathrm{t}$ and $\mathrm{t}+1$, or

Sales $_{\mathrm{t}+1}=\operatorname{Sales}_{\mathrm{t}}\left(1+\mathrm{g}_{\mathrm{t}+1}\right)$

Derive DIV $V_{t+1}$ :

The dividend paid by a firm is given by the portion of Net Income that is not retained as Addition to Retained Earnings (ARE). This is given by the equation

$$
D I V_{t+1}=N I_{t+1}-A R E_{t+1}
$$

From the assumptions, the interest expense as a fraction of debt (INT/Debt) and the tax rate (tax) are constant. Also, Sales grow at the rate of $g$ per year from time $t-1$ to time $t$, and at a rate of $g_{t+1}$ from time $t$ to time $t+1$, or

$$
\text { Sales }_{t+1}=\text { Sales }_{t}\left(1+g_{t+1}\right)
$$

Specify that (EBIT/Sales), (IC/Sales), and (Debt/IC) change by a factor of $f_{\mathrm{EBIT}}, \mathrm{f}_{\mathrm{IC}}$, and $\mathrm{f}_{\text {Debt }}$ respectively from time $\mathrm{t}$ to time $t+1$, which is defined as

$$
\begin{aligned}
f_{\text {EBIT }}\left(\frac{\text { EBIT }_{t}}{\text { Sales }_{t}}\right) & =\left(\frac{\text { EBIT }_{t+1}}{\text { Sales }_{t+1}}\right) \\
f_{I C}\left(\frac{\text { IC }_{t}}{\text { Sales }_{t}}\right) & =\left(\frac{\text { IC }_{t+1}}{\text { Sales }_{t+1}}\right) \\
f_{\text {Debt }}\left(\frac{\text { Debt }_{t}}{\text { IC }_{t}}\right) & =\left(\frac{\text { Debt }_{t+1}}{I C_{t+1}}\right)
\end{aligned}
$$

Multiplying the left side of Equations 15 and 16 by $\left(1+\mathrm{g}_{\mathrm{t}+1}\right) /\left(1+\mathrm{g}_{\mathrm{t}+1}\right)$ and factoring out Sales yields

$$
E B I T_{t+1}=f_{E B I T} E B I T_{t}\left(1+g_{t+1}\right)
$$




$$
I C_{t+1}=f_{I C} I C_{t}\left(1+g_{t+1}\right)
$$

Determine ARE $E_{t+1}$ :

Multiplying Equation 17 by Equation 19 yields

$$
\operatorname{Debt}_{t+1}=f_{\text {Debt }} f_{I C} \operatorname{Debt}_{t}\left(1+g_{t+1}\right)
$$

The definition of Invested Capital (IC) is the sum of Debt plus Equity. Therefore, subtracting Equation 20 from Equation 19 yields

$$
\text { Equity }_{t+1}=f_{I C} I C_{t}\left(1+g_{t+1}\right)-f_{\text {Debt }} f_{I C} \text { Debt }_{t}\left(1+g_{t+1}\right)
$$

Factoring out $\mathrm{f}_{\mathrm{IC}}\left(1+\mathrm{g}_{\mathrm{t}+1}\right)$ yields

$$
\text { Equity }_{t+1}=f_{I C}\left(1+g_{t+1}\right)\left[I C_{t}-f_{\text {Debt }} \text { Debt }_{t}\right]
$$

Adding and Subtracting Debt $t_{\mathrm{t}}$ within the term in brackets yields

$$
\text { Equity }_{t+1}=f_{I C}\left(1+g_{t+1}\right)\left[I C_{t}-\text { Debt }_{t}+\text { Debt }_{t}-f_{\text {Debt }} \text { Debt }_{t}\right]
$$

Simplifying yields

$$
\text { Equity }_{t+1}=f_{I C}\left(1+g_{t+1}\right)\left[\text { Equity }_{t}+\left(1-f_{\text {Debt }}\right) \text { Debt }_{t}\right]
$$

Subtracting Equity $y_{t}$ from both sides of Equation 24 and simplifying yields

$$
\Delta \text { Equity }_{t+1}=\left[f_{I C}\left(1+g_{t+1}\right)-1\right] \text { Equity }_{t}-f_{I C}\left(f_{\text {Debt }}-1\right)\left(1+g_{t+1}\right) \text { Debt }_{t}
$$

Assuming no issuance of new equity and clean surplus accounting, a change in Equity is solely due to the retention of Addition to Retained Earnings (ARE) from Net Income. Therefore, the ARE is equal to the change in Equity, or

$$
A R E_{t+1}=\left[f_{I C}\left(1+g_{t+1}\right)-1\right] \text { Equity }_{t}-f_{I C}\left(f_{\text {Debt }}-1\right)\left(1+g_{t+1}\right) \text { Debt }_{t}
$$

Determine $N I_{t+1}$ :

Net income can be defined as the difference between EBIT and Interest, after tax, or

$$
N I_{t+1}=\left(E B I T_{t+1}-I N T_{t+1}\right)(1-\operatorname{tax})
$$

The Interest expense is assumed to be the debt interest rate (i) times the level of debt. Inserting the relationship of Debt $_{\mathrm{t}}$ and Debt $_{\mathrm{t}+1}$ from Equation 20 yields

$$
I N T_{t+1}=i \operatorname{Debt}_{t+1}=f_{\text {Debt }} f_{I C} i \operatorname{Debt}_{t}\left(1+g_{t+1}\right)
$$

Substituting Equation 18 and 28 into Equation 27 yields

$$
N I_{t+1}=\left(1+g_{t+1}\right)\left[f_{E B I T} E B I T_{t}-f_{\text {Debt }} f_{I C} i \text { Debt }_{t}\right](1-t a x)
$$

Adding and subtracting EBIT $_{\mathrm{t}}$ and $\left(\mathrm{i} \mathrm{Debt}_{\mathrm{t}}\right)$ in the middle term in brackets on the right side of Equation 29, and recognizing that $\left(\mathrm{EBIT}_{\mathrm{t}}-\mathrm{i} \mathrm{Debt}_{\mathrm{t}}\right)(1-\mathrm{tax})$ is equal to $\mathrm{NI}_{t}$ yields

$$
N I_{t+1}=\left(1+g_{t+1}\right) N I_{t}-\left(1+g_{t+1}\right)(1-t a x)\left[\left(1-f_{E B I T}\right) E B I T_{t}+\left(f_{\text {Debt }} f_{I C}-1\right) i \text { Debt }_{t}\right]
$$

Assuming clean surplus accounting, $\mathrm{NI}_{\mathrm{t}}$ is equal to the sum of $\mathrm{DIV}_{\mathrm{t}}$ and $\mathrm{ARE}_{\mathrm{t}}$.

$$
N I_{t}=D I V_{t}+A R E_{t}
$$

The $\mathrm{ARE}_{t}$ is equal to the change in Equity, which is Equity $\mathrm{t}_{\mathrm{t}-1}$ minus Equity $\mathrm{or}_{\mathrm{t}} \mathrm{g}_{\mathrm{t}}$ Equity

$$
A R E_{t}=\Delta \text { Equity }_{t}=\left(\text { Equity }_{t}-\text { Equity }_{t-1}\right)=g_{t} \text { Equity }_{t-1}
$$

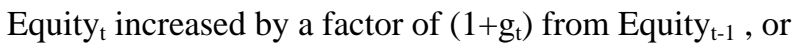

$$
\text { Equity }_{t}=\left(1+g_{t}\right) \text { Equity }_{t-1}
$$


or

$$
\text { Equity }_{t-1}=\left(\frac{\text { Equity }_{t}}{1+g_{t}}\right)
$$

Substituting Equation 34 into Equation 32 yields

$$
A R E_{t}=\Delta \text { Equity }_{t}=g_{t} \text { Equity }_{t-1}=\left(\frac{g_{t}}{1+g_{t}}\right) \text { Equity }_{t}
$$

Substituting Equation 35 into Equation 31 yields

$$
N I_{t}=D I V_{t}+\left(\frac{g_{t}}{1+g_{t}}\right) \text { Equity }_{t}
$$

Substituting Equation 36 into Equation 18 yields

$$
\begin{aligned}
& N I_{t+1}=\left(1+g_{t+1}\right) D I V_{t}+\left[g_{t} \frac{\left(1+g_{t+1}\right)}{\left(1+g_{t}\right)}\right] \text { Equity }_{t} \\
& \left.\quad-\left(1+g_{t+1}\right)\left[\left(1-f_{E B I T}\right) E B I T_{t}+\left(f_{\text {Debt }} f_{I C}-1\right) i \text { Debt }_{t}\right)(1-\text { tax })\right]
\end{aligned}
$$

Substituting Equations 37 and 26 into Equation 13 yields

$$
\begin{aligned}
\text { DIV }_{t+1}= & \left(1+g_{t+1}\right) D I V_{t}+\left[g_{t} \frac{\left(1+g_{t+1}\right)}{\left(1+g_{t}\right)}-g_{t+1}\right] \text { Equity }_{t} \\
& -\left(1-f_{E B I T}\right)\left(1+g_{t+1}\right)(1-\text { tax }) \text { EBIT }_{t} \\
- & \left(f_{\text {Debt }} f_{I C}-1\right)\left(1+g_{t+1}\right)(1-\text { tax })\left(\text { D Debt }_{t}\right) \\
& -\left(f_{I C}-1\right)\left(1+g_{t+1}\right) \text { Equity }_{t} \\
& +f_{I C}\left(f_{\text {Debt }}-1\right)\left(1+g_{t+1}\right) \text { Debt }_{t}
\end{aligned}
$$

If the (EBIT/Sales), (IC/Sales), and (Debt/IC) remain constant, then $\mathrm{f}_{\mathrm{EBIT}}, \mathrm{f}_{\mathrm{IC}}$, and $\mathrm{f}_{\text {Debt }}$ will be equal to 1 . Under this assumption, $\mathrm{DIV}_{\mathrm{t}+1}$ in Equation 38 simplifies to

$$
D I V_{t+1}=\left(1+g_{t+1}\right) D I V_{t}+\left[g_{t} \frac{\left(1+g_{t+1}\right)}{\left(1+g_{t}\right)}-g_{t+1}\right] \text { Equity }_{t}
$$

